ATTHULAB:

Islamic Religion Teaching \& Learning Journal

Volume 4 Nomor 2 Tahun 2019

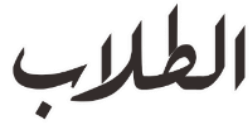

http://journal.uinsgd.ac.id./index.php/atthulab/

\title{
Profil pemahaman tenaga pendidik terhadap standar sarana dan prasarana
}

\author{
Siti Halimah \\ Makiya Foundation \\ Jalan Jati Cibiru Kota Bandung 40165 Indonesia \\ Email:sitihalimah9396@gmail.com
}

\begin{abstract}
Achieving National Standards of Education for madrassas is one of the successes and quality of education. So this research aims to obtain a profile of understanding and achievement of National Education Standards in the school environment. The research method used is a qualitative descriptive method using interview guidelines on national education standards. Data sources were obtained from school principals, vice principals, Islamic Education teachers, and Indonesian Language teachers. The results showed that there were variations in understanding of the standard of facilities and infrastructure. In addition, there are variations in components or aspects of standard infrastructure that are understood by principals and teachers. So the results of this study have implications for the importance of the socialization of standard evaluation components to all educators in a school/madrasa.

Keywords:

understanding profile; standard of facilities and infrastructure.
\end{abstract}

\begin{abstract}
Abstrak: Pencapaian Standar Nasional Pendidikan bagi madrasah merupakan salah satu keberhasilan dan mutu pendidikannya. Sehingga penelitian ini bertujuan untuk memperoleh profil pemahaman dan pencapaian Standar Nasional Pendidikan di lingkungan sekolah. Metode pnelitian yang digunakan ialah metode deskriptif kualitatif dengan menggunakan pedoman wawancara tentang standar nasional pendidikan. Sumber data diperoleh dari kepala sekolah, wakil kepala sekolah, guru Pendidikan Agama Islam, serta guru Bahasa Indonesia. Hasil penelitian menunjukkan bahwa adanya variasi pemahaman tentang standar sarana dan prasarana. Selain itu, terdapat variasi komponen atau aspek standar sarana prasarana yang dipahami oleh kepala sekolah dan guru-guru. Sehingga hasil penelitian ini berimplikasi terhadap pentingnya sosialisasi komponen-komponen standar evaluasi kepada seluruh pendidik di suatu sekolah/madrasah.
\end{abstract}

Kata Kunci:

profil pemahaman; standar sarana dan prasarana

DOI: http://dx.doi.org/10.15575/ath.v4i2.4600

Received: 05, 2019. Accepted: 10, 2019. Published: 11, 2019

\section{PENDAHULUAN}

Pendidikan merupakan karya bersama yang berlangsung dalam kehidupan insan tertentu yang memiliki sifat dan sarannya manusia itu sendiri. Pada pendidikan standar nasional ini, ada arah perubahan hasil pendidikan di negeri ini, yakni seperti dijelaskan Dinas Pendidikan Nasional bahwa pendidikan standar nasional yang bermutu yaitu pendidikan yang mampu mencapai standar mutu nasional dan internasioanal harus memiliki daya saing yang tinggi dalam hasil-hasil pendidikan (output dan outcomes), proses dan input sekolah baik secara nasional maupun internasional.

Undang-undang Republik Indonesia Nomor 20 tahun 2003 tentang sistem pendidikan nasional menyatakan bahwa sistem pendidikan nasional harus mampu menjamin pemerataan kesempatan pendidikan, peningkatan mutu serta relevansi dan 
efisiensi manajemen pendidikan dalam menghadapi tantangan sesuai dengan tuntutan peruahan kehidupan okal, nasional, dan global sehingga perlu adanya embaharuan pendidikan secara terencana, terarah, dan berkesinambungan.

Pendidikan nasional berfungsi dalam mengembangkan kemampuan dan membentuk peradaban bangsa yang bermartabat dalam rangka mencerdaskan kehidupan bangsa. Sedangkan tujuan pendidikan nasional adalah mengembangkan potensi peserta didik agar menjadi manusia yang beriman dan bertakwa kepada Tuhan Yang Maha Esa, berakhlak mulia, sehat, berilmu, cakap, kreatif, mandiri, dan menjadi warga negara yang demokratis serta bertanggungjawab.

Penerapan tujuan pendidikan nasional tersebut diawali pada pendidikan dasar yang terdiri dari sekolah dasar (SD) dan sekolah menengah pertama (SMP). Program ini sedang dilaksanakan oleh pemerintah )pusat/ provinsi, dan kabupaten/kota) yakni dengan adanya wajib belajar sembilan tahun, yakni setiap warga negara yang berumur tujuh tahun sampai lima belas tahun wajib mengikuti pendidikan dasar yang diadakan oleh pemerintah. Padahal kenyataa yang terjadi saat ini adalah dengan terjadinya perbedaan yang cukup signifikan antara mutu pendidikan di kota-kota besar dengan di daerah-daerah.

Dalam rangka tercapainya tujuan pembangunan nasional, pendidikan mempunyai peran yang sangat penting. Oleh karena itu, pemerintah akan terus meningkatkan pembangunan pendidikan yang bermutu. Berbagai kebijakan strategis untuk peningkatan mutu pendidikan telah ditetapkan pemerintah, salah satu di antaranya adalah Peraturan Pemerintah Nomor 19, Tahun 2005 tentang Standar Nasional Pendidikan (SNP) (PP No. 19 Tahun 2005). SNP merupakan acuan dalam rangka mengembangkan mutu pendidikan dan telah dijabarkan menjadi delapan standar, yaitu 1) Standar Isi; 2) Standar Kompetensi Lulusan; 3) Standar Kompetensi Pendidik dan Tenaga Kependidikan; 4) Standar Proses; 5) Standar Pengelolaan; 6) Standar Sarana Prasarana; 7) Standar Pembiayaan; dan 8) Standar Penilaian. (Amrozi, 2011)

Keberadaan SNP diharapkan dapat menjamin mutu pendidikan di Indonesia dalam arti yang luas, yaitu mencerdaskan kehidupan bangsa dan membentuk watak serta peradaban bangsa yang bermartabat. Namun, adanya standar pendidikan sering juga menghambat peningkatan mutu karena adanya potensi negatif yang tersembunyi, yaitu adanya pendidikan yang terkungkung hanya karena ketentuan standar sehingga kehilangan makna terhadap tujuan pendidikan yang akan dicapai. Oleh karena itu, pada ketentuan SNP dinyatakan juga bahwa SNP perlu disempurnakan secara terencana, terarah, dan berkelanjutan sesuai dengan tuntutan perubahan kehidupan lokal, nasional, dan global. (Triwiyanto, 2013)

Penelitian BAN Sekolah/Madrasah menunjukkan bahwa terdapat jumlah satuan pendidikan yang cukup besar tidak memenuhi SNP, sehingga memerlukan dukungan dana dari pemerintah agar dapat memenuhi SNP. Komponen SNP yang belum sepenuhnya dapat dipenuhi terkait dengan standar kompetensi lulusan, standar pendidik dan kependidikan, serta standar sarana prasarana (Subijanto, 2012). Hasil penelitian yang lain juga memperkuat bahwa standar sarana prasarana merupakan standar yang pemenuhannya masih kurang. Dari delapan standar yang ada, standar yang masih rendah adalah standar sarana prasarana, standar proses, standar kompetensi, dan standar tenaga pendidik dan kependidikan. (Firdaus, 2013)

Salah satu SNP yang penting dalam upaya peningkatan mutu pendidikan adalah standar sarana dan prasarana. Layanan sarana dan prasarana bertujuan untuk memenuhi standar nasional yang ditetapkan. Standar sarana dan prasarana merupakan 
standar minimal yang harus dipenuhi oleh setiap satuan pendidikan. Standar dimaksud meliputi gedung (ruang belajar), lahan, perpustakaan, dan prasarana lainnya yang digunakan dalam pembelajaran. Dalam kenyataannya, pemenuhan standar sarana dan prasarana itu belum maksimal. Dari berbagai informasi yang diperoleh dinyatakan, bahwa masih banyak gedung sekolah yang tidak layak untuk pembelajaran. Sekolah masih banyak yang belum mempunyai perpustakaan dan prasarana belajar lainnya. (Bandhopadhyay, 2009)

Dengan melihat kondisi serta fenomena yang telah dikemukakan, dapat dipahami bahwa pengelolaan sarana dan prasarana sekolah sangatlah penting untuk dilaksanakan. Tanpa adanya pengelolaan, sarana dan prasarana yang dimiliki tidak mampu memberikan kontribusi sebagaimana tujuan diadakannya. Pengelolaan tersebut seperti analisis kebutuhan sekolah, pengadaan inventarisasi, serta pemeliharaan yang optimal sangat dibutuhkan agar nantinya sarana dan prasarana yang dimiliki mampu berjalan dengan optimal sesuai dengan tujuan diadakannya dan selalu dalam kondisi siap digunakan.(Moh. Munir, 2014)

Adanya pengelolaan sarana dan prasarana yang baik dan optimal, maka dalam setiap proses pendidikan di sekolah akan berjalan sesuai dengan apa yang diharapkan karena didukung ketersediaan fasilitas yang lengkap dan tepat sesuai kebutuhan sehingga berdampak pada mutu dan kualitas setiap proses pendidikan di sekolah.(Soeharto, 2012)

Tujuan PP (Peraturan Pemerintah) Nomor 9 Tahun 2005 tentang Standar Nasional Pendidikan adalah untuk meningkatkan mutu pendidikan yang tercermin dalam hasil belajar siswa. Mengingat Peraturan Pemerintah tersebut relatif baru diterbitkan belum meliputi parameter dalam standar nasional pendidikan. Dengan demikian, penelitian mengenai sarana dan prasarana di sekolah menengah berdasarkan pada parameter SNP untuk mengidentifikasi kesenjangan dengan standar tersebut. Karena sarana prasarana itu juga akan memberikan kontribusi pada peningkatan mutu pendidikan serta dapat digunakan sebagai acuan penanganan bilamana dihadapkan pada keterbatasan sumber daya dalam meningkatkan tiga komponen masukan instrumental tersebut sekaligus.(Supandi, 2007)

Peningkatan mutu pendidikan akan tercapai apabila proses belajar mengajar yang diselenggarakan di kelas benar-benar efektif dan berguna untuk mencapai kemampuan pengetahuan, sikap dan keterampilan yang diharapkan. (Gazali, 2013) Sebagaimana yang dikemukanan oleh Sardi bahwa standar mutu pendidikan sesuai ISO bahwa komponen standar sarana dan prasarana, memiliki sasaran mutu yaitu semua bahan ajar yang diperlukan siswa tersedia, dan juga menambah sarana dan prasarana.(Sardi, 2012)

Penggunaan delapan standar nasional sebagai tolok ukur, sejalan dengan pendapat yang dikemukakan oleh Simons, Burko, dan Wolf yang mengukur kapasitas pendidikan melalui enam dimensi yakni principal leaership, professional community, program coherence, technical resources, knowledge, skills and dispositions of individual teachers, and learning opportunities for teachers. Penekanan keenam dimensi tersebut lebih berorientasi pada guru dan tenaga kependidikan, sedangkan koherensi program dimaknai mencakup pada tujuh standar lainnya.(Soeharto, 2012)

Karena pada dasarnya proses belajar mengajar merupakan inti dari proses pendidikan secara keseluruhan, diantaranya guru merupakan salah satu faktor yang penting dalam menentukan berhasilnya proses belajar mengajar di dalam kelas. Oleh karena itu guru dituntut untuk meningkatkan peran dan kompetensinya, guru yang kompeten akan lebih mampu menciptakan lingkungan belajar yang efektif dan akan 
lebih mampu mengelola kelasnya sehingga hasil belajar siswaberada pada tingkat yang optimal. (Megasari, 2014)

Penelitian terdahulu yang relefan dengan penelitian yang peneliti lakukan yaitu penelitian yang dilakukan oleh Tjahyani Busono mengenai evaluasi pemenuhan standar minimal sarana dan prasarana pendidikan dasar di kota Bandung yang bertujuan untuk memperoleh gambaran kondisi sarana dan prasarana pendidikan dasar berdasarkan standar sarana dan prasarana sekolah/madrasah umum sesuai dengan Permendiknas 24 Tahun 2007.(Busono, 2011) Perbedaan penelitian yang dilakukan oleh peneliti dengan penelitian sebelumnya yaitu pada fokus penelitiannya. Penelitian ini bertujuan untuk mengetahui pemahaman tenaga pendidik terhadap standar sarana dan prasarana. Sedangkan penelitian terdahulu yang relevan berfokus untuk mengetahui gambaran terkait luas bangunan sekolah dengan kesesuaian dengan standar yang telah ditetapkan.

\section{METODE PENELITIAN}

Penelitian ini menggunakan metode deskriptif kualitatif (Sugiyono, 2011) dengan menggunakan pedoman wawancara serta angket tentang standar nasional pendidikan sarana prasarana mengenai luas lahan, luas bangunan, serta kelengkapan sarana dan prasarana yang meliputi ruang kelas,ruang perpustakaan,ruang laboratorium IPA, ruang pimpinan, ruang guru, ruang tata usaha, tempat beribadah, ruang konseling, ruang UKS, ruang organisasi kesiswaan, jamban, gudang, ruang sirkulasi,tempat bermain/berolahraga.

Sumber data diperoleh dari kepala sekolah, wakil kepala sekolah, guru Pendidikan Agama Islam serta guru Bahasa Indonesia. Tujuan penelitian yaitu untuk mengetahui pemahaman tenaga pendidik terhadap standar sarana dan prasarana serta angket yang digunakan bertujuan untuk menanyakan pendapat responden mengenai pemahaman responden terhadap Standar nasional Pendidikan Sarana dan Prasarana dengan cara mengumpulkan informasi serta menjamin validitas informasi yang diperoleh.

Bentuk angket yang digunakan yaitu angket tertutup (closed questionnaire) yakni pertanyaan yang diajukan dengan bentuk memilih salah satu dari dua alternatif ( Force Choice Item ). (Arikunto, 2006) Jawaban hanya terdiri dari dua alternatif yang harus dipilih salah satu diantaranya, yaitu dengan memilih/mengisi kolom Ya atau Tidak dengan jumlah 41 item pertanyaan.

Lokasi penelitian berlokasi di MTs Kifayatul Achyar di jalan AH. Nasution, Cibiru Bandung. Analisis data akan diolah dengan cara mendeskripsikan data, menyajikan data dalam bentuk grafik dan tabel, menginterpretasi serta menganalisis data.

\section{HASIL PENELITIAN DAN PEMBAHASAN}

Ketercapaian standar sarana dan prasarana pendidikan dapat diperoleh dengan membandingkan ketentuan standar sarana dan prasarana dengan kondisi tersedia pada satuan pendidikan baik kuantitas, kualitas, maupun spesifikasi sarana tersebut sesuai dengan peruntukannya. Kesesuaian antara ketentuan standar dengan kondisi nyata di lapangan merupakan ketercapaian standar yang dinyatakan dengan pernyataan guru yang menggambarkan tingkat ketercapaian standar sarana dan prasarana pendidikan di satuan pendidikan. (Nur'aini, 2015)

Pemeliharaan sarana dan prasarana merupakan kegiatan perawatan sarana dan prasarana yang dimiliki untuk meminimalisir kerusakan agar selalu dalam kondisi yang baik, dan siap pakai. Temuan penelitian engenai pemeliharaan sarana dan prasarana dilakukan dengan melibatkan seluruh warga sekolah, pemeliharaan juga dilaksanakan 
dengan mengadakan tata tertib, himbauan dan pendekatan ke kelas-kelas, dan juga bentuk pemeliharaan terdapat perawatan dan perbaikan.

Salah satu lingkup standar nasional pendidikan yaitu standar sarana dan prasarana yang meliputi hal-hal sebagai berikut: sarana pendidikan pada setiap satuan pendidikan wajib dimiliki, yang meliputi perabot, peralatan pendidikan, media pendidikan, buku dan sumber belajar lainnya, bahan habis pakai, serta perlengkapan lainnya yang diperlukan dalam menunjang proses pembelajaran yang teratur dan berkelanjutan. Prasarana pendidikan pada setiap satuan pendidikan wajib dimiliki, yang meliputi lahan, ruang kelas, ruang pimpinan satuan pendidikn, ruang pendidik, ruang tata uasaha, ruang perpustakaan, ruang laboratorium, ruang bengkel kerja, ruang unit produksi, ruang kantin, instalasi daya dan jasa, tempat berolahraga, tempat beribadah, tempat bermain, tempat berkreasi dan ruangan/tempat lain yang diperlukan dalam menunjang proses pembelajaran yang teratur dan berkelanjutan. Untuk melaksanakan amanat tersebut, pemerintah menerbitkan peraturan Mneteri Pendidikan Nasional (Permendiknas) No. 4 Tahun 2007 tentang standar sarana dan prasarana SD/MI, SMP/MTS, dan SMA/MA yang memiliki harapan agar tujuan pendidikan pada setiap pendidikan yang telah dirancang pada Undang-undang Sistem Pendidikan NNAsional nomor 20 Tahun 2003 segera terwujud.(Teguh Triwiyanto, 2013)

Dalam pemeliharaan sarana dan prasarana yang peneliti temukan dalam penelitian ini, pada dasarnya sudah sesuai dengan yang diungkapkan oleh Arifin yang mengemukakan bahwa ada lima tahapan yang perlu diperhatikan pengelola sekolah yaitu: (1) penyadaran yaitu penanaman kesadaran kepada warga sekolah terkait pentingnya pemeliharaan sarana dan prasarana, (2) pemahaman yaitu memberikan pemahaman mengenao program pemeliharaan, (3) pengorganisasian yakni maksudnya penyusunan struktur organisasi dan pembagian tugas pemeliharaan sarana dan prasarana, wewenang serta tanggung jawab, (4) pelaksanaan yaitu pelaksanaann sarana dan prasarana sekolah secara teratur sehingga menjadi suatu kebiasaan civitas sekolah, (5) pendataan maksudnya inventarisasi sarana dan prasarana ditinjau dari ketersediaan dan kondisinya.(Arifin, 2012)

Berdasarkan analisis data pemahaman tenaga pendidik terhadap standar sarana dan prasarana diperoleh profil pemahaman tenaga pendidik dan profil analisis hasil instrumen standar sarana dan prasarana pada Madrasah Tsanawiyah Kifayatul Achyar:

Profil pemahaman tenaga pendidik dapat ditunjukkan dengan grafik berikut:

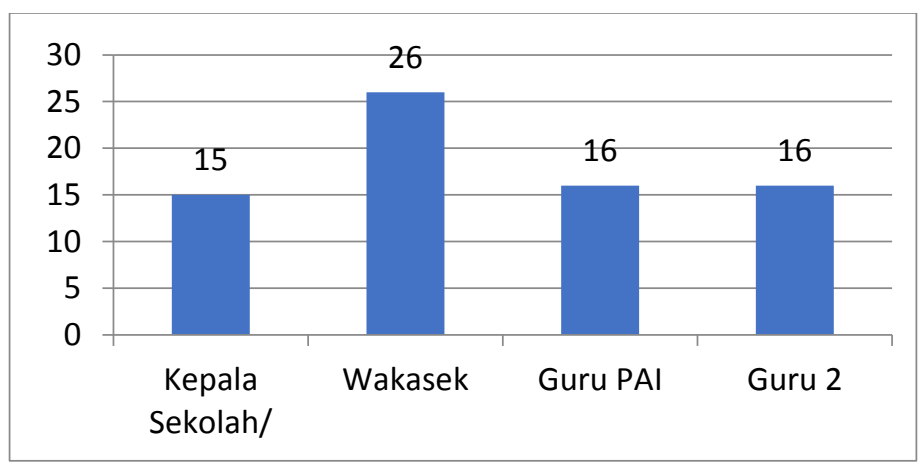

Grafik 1: Profil Pemahaman Tenaga Pendidik terhadap Standar Sarana dan Prasarana 
Grafik 1 menunjukkan adanya perbedaan antara pemahaman kepala sekolah, wakil kepala sekolah, guru PAI dan guru Bahasa Indonesia terhadap komponen standar sarana dan prasarana. Pernyataan dari wakil kepala sekolah menunjukkan perbedaan yang signifikan dengan jawaban terbanyak yaitu dengan menjawab Ya sebanyak 26 item, kemudian jawaban guru 1 dan guru 2 menunjukkan jawaban Ya sebanyak 16 item, lalu Kepala Sekolah dengan jawaban Ya paling sedikit diantara yang lain yakni dengan jawaban Ya sebanyak 15.

Perbedaan pernyataan antar tenaga pendidik terdapat pada butir item ke 6 mengenai kondisi bangunan yang belum memenuhi unsur keselamatan, item ke 7 bahwa madrasah belum memiliki sarana sanitasi, item ke 8 terkait madrasah tidak memiliki sarana ventilasi dan pencahayaan, item ke 10 bahwa madrasah belum memiliki izin legalitas atas bangunan, item 12 mengenai inventarisasi bangunan, item ke 14 bahwa madrasah belum memiliki laboratorium komputer, item ke 17 bahwa ruang kelas madrasah secara keseluruhan perabot, peralatan, dan perlengkapan lain pada ruang kelas, ketercapaian ruang kelas belum maksimal. Hal ini dikarenakan ketepatan perabotan dan perlengkapan lainnya sudah tidak sesuai dengan kebutuhan proses pembelajaran pada saat ini, item ke 20 bahwa laboratorium IPA di madrasah belum memenuhi standar minimal, item ke 21 dan 22 bahwa madrasah tidak memiliki ruang pimpinan, item ke 25 bahwa madrasah tidak memiliki ruang tata usaha, serta item ke 41 bahwa tempat bermain/berolahraga madrasah belum memenuhi standar minimal sarana prasarana karena tempat bermain/berolahraga secara fungsi adalah sebagai area bermain, berolahraga pendidikan jasmani, upacara bendera, dan tempat kegiatan pembelajaran di luar kelas.

Perbedaan pemahaman antar guru terhadap standar sarana dan prasarana diduga ditentukan oleh kurangnya pelatihan dan sosialisasi yang diperuntukkan bagi tenaga pendidik. (Fauzi, 2016) Pelatihan dan sosialisasi merupakan aspek penting terutama bagi para pendidik agar menambah pemahaman mengenai standar nasional pendidikan yang harus dipenuhi oleh setiap masing-masing lembaga. (Arif, 2013)

Padahal guru merupakan salah satu faktor penentu yang paling besar terhadap mutu pendidikan. Sebagaimana hasil studi dai bank dunia yang menunjukkan bahwa faktor guru menentukan 34\% mutu guru untuk negara berkembang dan sebesar 36\% untuk negara maju.(Kasman, 2010) Dengan demikian, lebih dari sepertiga variasi mutu pendidikan dapat dijelaskan oleh variabel guru. Mutu guru dicirikan oleh penguasaan yang mendalam terhadap materi tyang diajarkan, kemampuan dalam menyajikan dan menyesuaikan materi tersebut dalam pembelajaran, keterampilan mengelola kelas sehingga memungkinkan siswa belajar aktif, dan juga ditandai dengan pemahaman guru terhadap standar nasional pendidikan yang telah ditentukan termasuk standar nasional pendidikan sarana dan prasarana.(Chairunnisa, 2013) Seyogyanya seorang guru juga memahami delapan standar tersebut sehingga tidak terjadi perbedaan pendapat. Dengan demikian, hendaknya setiap lembaga pendidikan mengadakan pelatihan ataupun pembinaan yang dapat menunjang pengetahuan guru.(Dewi, 2013)

Bentuk pembinaan dan pengembangan profesi guru di madrasah dapat dilaksanakan melalui kegiatan-kegiatan antara lain pembinaan internal yang dilaksanakan oleh kepala madrasah dan guru-guru yang memiliki kewenangan membina, melalui rapat dinas, rotasi tugas mengajar, pemberian tugas-tugas internal tambahan, diskusi masalah-masalah pendidikan yang diselenggarakan secara berkala dengan topik diskusi sesuai dengan masalah yang dialami di madrasah, (Prihartini, 2014) (Ismail, 2010) kegiatan kolektif guru dalam mengikuti kegiatan pertemuan ilmiah atau untuk mengikuti kegiatan bersama yang dilakukan guru yang bertujuan untuk 
meningkatkan keprofesian guru yang bersangkutan, seperti mengikuti lokakarya atau kegiatan kelompok/musyawarah kerja guru atau in house training untuk penyusunan perangkat kurikulum, pengembangan media pembelajaran, seminar workshop, simposium, dan atau pertemuan ilmiah lainnya. (Asmendri, 2014) (Usman, 2008) Selain itu, kegiatan lain yang dapat dilakukan seperti pengikutsertaan guru dalam pertemuan ilmiah juga dapat menjadi model pembinaan berkelanjutan bagi peningkatan profesionalitas guru dalam upaya peningkatan kualitas pendidikan, juga kegiatan melalui kemitraan madrasah yang dapat dilaksanakan antara madrasah yang baik dengan yang kurang baik, antara madrasah negeri dengan madrasah swasta, dan sebagainya. (Arif, 2013)Selain itu, untuk meningkatkan kompetensi pendidik diperlukan prasyarat yang memadai dari pengampu kebijakakn sekolah.

Analisis Komponen Standar Sarana dan Prasarana. Berdasarkan pertanyaan peneliti yang dijawab oleh responden mengenai standar sarana dan prasarana dengan jumlah 41 pertanyaaan dapat disajikan dalam tabel 1 berikut:

Tabel 1. Distribusi Hasil Instrumen

\begin{tabular}{cccccc}
\hline No. & Responden & Ya & Persentase & Tidak & Persentase \\
\hline 1. & Kepala Sekolah & 15 & $6,15 \%$ & 26 & $10,66 \%$ \\
2. & Wakil Kepala Sekolah & 26 & $10,66 \%$ & 15 & $6,15 \%$ \\
3. & Guru 1 & 16 & $6,56 \%$ & 25 & $10,25 \%$ \\
4. & Guru 2 & 16 & $6,56 \%$ & 25 & $10,25 \%$ \\
& Rata-rata & 18,25 & $0,73 \%$ & 22,75 & $0,91 \%$ \\
\hline
\end{tabular}

Berdasarkan tabel 1 distribusi hasil instrumen, diperoleh hasil rerata pemahaman tenaga pendidik terhadap standar nasional pendidikan sarana dan prasarana dengan jumlah 0,73\% pada jumlah jawaban Ya dan 0,91\% dengan jumlah jawaban Tidak. Terdapat indikasi bahwa adanya kesamaan pemahaman antara guru 1 dan guru 2 dengan persentase $6,56 \%$, sementara itu hasil pernyataan dari kepala sekolah juga memiliki pemahaman yang tidak jauh beda dengan pemahaman kedua guru tersebut dengan persentase $6,15 \%$. Perbedaan pemahaman yang signifikan terjadi pada jawaban pernyataan dari wakil kepala sekolah dengan hasil persentase $10,6 \%$.

Pernyataan dari wakil kepala sekolah menunjukkan jawaban terbanyak yaitu dengan menjawab Ya sebanyak 26 item. Pernyataan Tidak yang dikemukakan wakil kepala sekolah terdapat pada butir item ke 5 yaitu mengenai lahan bangunan yang tidak memenuhi ketentuan standar minimum, item ke 13 mengenai kelengkapan sarana prasarana sekolah yang tidak memenuhi kelengkapan sebanyak 14 ruang, butir item ke 15 mengenai laboratorium bahasa, item ke 16 bahwa sekolah/madrasah tidak memenuhi standar rasio luas ruang kelas, item 19 yang menunjukkan bahwa sarana prasarana perpustakaan madrasah belum memenuhi standar minimal, item ke 20 mengenai belum adanya laboratorium IPA, item ke 23 yang menyatakan bahwa madrasah belum memiliki ruang diskusi MGMP, item ke 24 yang memberikan pernyataan bahwa ruang guru belum memenuhi standar minimal seperti belum lengkapnya kursi dan meja tamu, papan statistik, kursi kerja, meja kerja, lemari, dan papan pengumuman, sedangkan pada perlengkapan lain terdiri dari tempat sampah, tempat cuci tangan, dan jam dinding yang secara keseluruhuhan ketercapaian pada ruang guru belum maksimal, item ke 26 yang menunjukkan bahwa ruang Tata Usaha belum memenuhi standar minimal, item ke 30 yang menyatakan bahwa ruang konseling madrasah belum memenuhi standar minimal, item ke 31 bahwa madrasah belum memiliki ruang UKS, item ke 32 bahwa ruang konseling madrasah belum memenuhi 
standar minimal, item ke 34 mengenai ruang organisasi kesiswaan yang belum memenuhi standar minimal, item ke 36 menyatakan bahwa jamban belum memenuhi standar minimal karena belum memenuhi standar luasnya, belum ditunjang oleh ketersediaan air bersih, serta belum dilengkapi oleh sarana penunjang di dalamnya seperti gantungan pakaian, tempat sampah, tempat air, gayung, dan kloset jongkok yang mengindikasikan ketercapaian kepemilikan jamban belum mencapai sesuai dengan standar yang telah ditentukan (Dewi, 2011), dan item ke 38 sarana prasarana gudang belum memenuhi standar minimal.

Perbedaan yang signifikan inilah yang perlu ditelusuri karena boleh jadi perbedaaan ini diakibatkan oleh ketidakpahaman guru terhadap fungsi dan pemanfaatan sarana dan prasarana pendidikan, tidak semua guru mau menggunakan sarana dan prasarana pendidikan, minimnya keberadaan sarana dan prasarana pendidikan di sekolah, dan yang paling penting yaitu kurangnya pemahaman tenaga pendidik terhadap standar nasional pendidikan sarana dan prasarana yang mestinya mereka kuasai. Sarana dan prasarana pendidikan merupakan salah satu faktor pendidikan yang keberadaannya sangat mutlak dalam proses pendidikan. Salah satu contohnya dalam hal kegiatan administrasi sarana dan prasarana pendidikan yang meliputi perencanaan, prakualifikasi, pengadaan, penyimpanan, pemeliharaan, penghapusan dan pengendalian. Fakta di lapangan ternyata masih ditemui berbagai persoalan pengelolaan sarana dan prasarana pendidikan yakni kurangnya pemahaman tenaga pendidik terhadap pengelolaan sarana dan prasarana pendidikan sesuai praktek dan teorinya. (Kurniawati, 2013)

\section{SIMPULAN}

Berdasarkan analisis data dan pembahasan (diskusi), maka diperoleh adanya variasi pemahaman tentang standar sarana dan prasarana di sekolah/madrasah pada berbagai komponen sarana dan prasarana yang ada di MTs Kifayatul Achyar. Adanya variasi pemahaman disebabkan kurangnya kegiatan pelatihan dan sosialisasi agar tenaga pendidik memahami fungsi dan pemanfatan mengenai standar nasional pendidikan khususnya pada standar sarana dan prasarana. Salah satu solusinya yaitu dengan dilaksanakannya pembinaan internal yang dilaksanakan oleh kepala madrasah dan guru-guru yang memiliki kewenangan membina, melalui kegiatan sosialisasi dan pelatihan, serta diskusi masalah-masalah pendidikan juga dengan dilaksanakannya kegiatan melalui kemitraan madrasah. Selain itu, peneliti juga menyarankan kepada pihak sekolah agar kebutuhan lahan untuk aktivitas siswa dan pemenuhan standar sarana dan prasarana mutlak harus dipenuhi, sedangkan di marasah tsanawiyah Kifayatul Achyar mengalami kesulitan dalam melaksanakan pelruasan lahan, untuk memenuhi hal tersebut dapat dilaksanakan dengan melaksanakan pembangunan dengan menambah jumlah lantai bangunan dan melakukan penghapusan beberapa bangunan untuk dijadikan lahan tempat aktivitas siswa melaksanakan olahraga atau upacara serta memenuhi kebutuhan ruang terbuka hijau (taman), dan juga peneliti menyarankan bahwa pihak sekolah hendaknya melalksanakan pemenuhan ruang pendukung seperti ruang guru yang lebih luas, UKS, dan juga mushola dapat dipenuhi dengan mengefektifkan ruang-ruang yang dimiliki dan menambah ruang baru. Karena bagi sekolah yang memiliki lahan sempit, pemenuhan kebutuhan ruang tersebut haruslah diusahakan tidak mengambil lahan yang masih tersedia, akan tetapi melaksanakan pembangunan dengan menambah jumlah lantai sesuai dengan ketentuan yang berlaku. 


\section{REFERENSI}

Amrozi. (2011). Kesesuaian Sarana Prasarana, Kompetensi Guru, Manajemen, Dan Proses Praktikum Prodi Keahlian Teknik Otomotif Smk Ditinjau Dari Standar Peraturan Pemerintah Ri Nomor 19 Tahun 2005. Teknologi Dan Kejuruan, Vol. 34, $N, 23-34$.

Arif, S. (2013). Orientasi Pembinaan Dan Pengembangan Profesi Guru Di Madrasah. Tadris: Jurnal Pendidikan Islams, Volume 81.

Arifin, B. Dan. (2012). Manajemen Sarana Dan Prasarana Sekolah. Yogyakarta: Ar-Ruzz Media.

Arikunto, S. (2006). Prosedur Penelitian Suatu Pendekatan Praktik. Jakarta: Rineka Cipta.

Asmendri. (2014). Kompetensi Kepala Madrasah Dalam Pelaksanaan Delapan Standar Nasional Pendidikan (Snp). Ta'dib, Volume 17,.

Bandhopadhyay, M. (2009). Present Status Of Infrastructure Facilities In Schools In India: From National And State Level Perspective. National University Of Educational Planning And Administration.

Busono, T. (2011). Evaluasi Pemenuhan Standar Minimal Sarana Dan Prasarana Pendidikan Dasar Di Kota Bandung. Invotec, Vii, No. 1, 81-91.

Chairunnisa, C. (2013). Kepemimpinan, Sistem, Dan Struktur Organisasi, Lingkungan Fisik, Dan Kefektifan Organisasi Sekolah. Jurnal Ilmu Pendidikan, 19(1), 56-60.

Dewi. (2013). Kinerja Kepala Sekolah: Pengaruh Kepemimpinan Transformasional Konflik Dan Efikasi Diri. Jurnal Ilmu Pendidikan, 19(1), 150-166.

Dewi, I. K. H. (2011). Evaluasi Program Smp Standar Nasional Berdasarkan Standar Nasional Pendidikan. Jurnal Pendidikan Dan Kebudayaan, Vol. 17, N. Retrieved From Https://Jurnaldikbud.Kemdikbud.Go.Id/Index.Php/Jpnk/Article/Viewfile/54 $/ 51$

Fauzi, A. (2016). Strategi Pengembangan Madrasah. Jurnal Tarbawi, Volume 2.

Firdaus, I. (2013). Standar Pelayanan Minimum Pendidikan (Studi Kasus Manajemen Sarana Dan Prasarana Pendidikan Di Sekolah Laboratorium-Percontohan Upi Bandung), Vol 1, No. Retrieved From Http:/ /Ejournal.Upi.Edu/Index.Php/Ear/Article/View/1114

Gazali, M. (2013). Optimalisasi Peran Lembaga Pendidikan Untuk Mencerdaskan Bangsa. Jurnal Al-Ta'dib, Vol. 6 No.

Ismail, M. I. (2010). Kinerja Dan Kompetensi Guru Dalam Pembelajaran. Jurnal Lentera Pendidikan, 13 No. 1.

Kasman. (2010). Improvisasi Manajemen Kurikulum Dan Pembelajaran Sekolah Bermutu. Jurnal Manajemen Pendidikan, 23(2), 122-130. 
Kurniawati, P. I. (2013). Manajemen Sarana Dan Prasarana Di Smk N 1 Kasihan Bantul. Akuntabilitas Manajemen Pendidikan, Volume 1,.

Megasari, R. (2014). Peningkatan Pengelolaan Sarana Dan Prasarana Pendidikan Untuk Meningkatan Kualitas Pembelajaran Di Smpn 5 Bukittinggi. Jurnal Administrasi Pendidikan, Volume 2 N.

Moh. Munir. (2014). Manajemen Sarana Dan Prasarana Dalam Upaya Peningkatan Mutu Pendidikan Di Sma Negeri2 Suarabaya. Jurnal Inspirasi Manajemen Pendidikan, 4 No. 4.

Nur'aini, E. (2015). Evaluasi Standar Sarana Prasarana Di Smp Negeri I Banguntapan Bantul Yogyakarta, Vol: Xxii.

Prihartini, Y. (2014). Dasar-Dasar Pengembangan Profesi Guru Menurut Teori Dan Praksis Pendidikan. Jurnal Penelitian Sosial Keagamaan, Vol 4 (201. Retrieved From Http://E-Journal.Iainjambi.Ac.Id/Index.Php/Kontektualita

Sardi. (2012). Bahan Ajar Penyusunan Bisnis Proses Kebijakan Mutu Sasaran Mutu. Yogyakarta: Pusat Pengembangan Dan Pemberdayaan Pendidikan Dan Tenaga Kependidikan Seni Dan Budaya.

Soeharto. (2012). Pencapaian Standar Nasional Pendidikan Di Sekolah Menengah Kejuruan Daerah Istimewa Yogyakarta. Cakrawala Pendidikan, Xxxi(1).

Subijanto, S. W. (2012). Analisis Kinerja Badan Akreditasi Nasional Sekolah/Madrasah. Jurnal Pendidikan Dan Kebudayaan, 18 (3), 310-318.

Sugiyono. (2011). Metode Penelitian Pendidikan. Bandung: Alfabeta.

Supandi. (2007). Kesenjangan Antara Kondisi Pendidik, Pengelolaan serta Sarana dan Prasarana di Provinsi Banten dengan Standar Nasional Pendidikan. Alqalam, 24 No. 3.

Teguh Triwiyanto. (2013). Standar Nasional Pendidikan Sebagai Indikator Mutu Layanan Manajemen Sekolah. Jurnal Ilmu Pendidikan, 19(2).

Triwiyanto, T. (2013). Standar Nasional Pendidikan sebagai Indikator Mutu Layanan Manajemen Sekolah. Jurnal Ilmu Pendidikan, 19(2), 161.

Usman, M. U. (2008). Menjadi Guru Profesional. Bandung: Remaja Rosdakarya. 